\title{
INDONESIAN FINTECH: BUSINESS ECOSYSTEM AND REGULATION
}

\author{
${ }^{1}$ Sugeng, ${ }^{2}$ Clara Ignatia Tobing, ${ }^{3}$ Rona Fajarwati \\ ${ }^{1}$ Faculty of Law, Universitas Bhayangkara Jaya, sugeng@dsn.ubharajaya.ac.id \\ ${ }^{2}$ Faculty of Law, Universitas Bhayangkara Jaya, claraignatiatobing@gmail.com \\ ${ }^{3}$ Faculty of Law, Universitas Bhayangkara Jaya, ronaafwshmh@gmail.com
}

\begin{abstract}
This article will examine the development of the business ecosystem and regulation of Financial Technology (Fintech) in Indonesia, especially lending through electronic transactions, or peer to peer lending (P2P Lending). Although the Financial Services Authority (OJK) has closed the company's activities, but in a short time other illegal companies have emerged, even in larger numbers. This research uses the doctrinal method with the statutory approach. Secondary data is used to explain of legal and social phenomena related to the research topic.The Fintech industry requires specific provisions governing criminal offenses related to Illegal companies.
\end{abstract}

Keywords: Fintech; P2P Lending; Business Ecosystem

\section{Introduction}

Internet users in the world are increasing significantly. in the first ten years of the $21 \mathrm{st}$ century, the number of people connected to the internet rose from over 350 million to over 2 billion. In 2015, there were 3 billion internet users worldwide. Then, in 2018, the earth's population that has been connected to the internet has reached more than 4 billion. This amount is equivalent to 52.96 percent of the world's total population, amounting to 7.59 billion. $^{1}$

Internet penetration in Indonesia is also amazing. The survey of the Indonesian Internet Service Providers Association (APJII) shows that out of a total population of 264 million Indonesians, 171.17 million (64.8\%) have been connected to internet services, up 10.12 percent compared to the previous year. They are constantly connected and penetrate internet sites, which currently number more than 1.24 billion. As noted, in the 2000 s, internet users in Indonesia were still around 2 million people. ${ }^{2}$ If observed since the last twenty years, the increase in internet users has steadily increased by more than $10 \%$ per year. $^{3}$

The widespread use of the internet has changed society in its social life. Through an internet connection, some people can buy various items on-line, send goods through digital services, order food and use public transportation services through digital applications, read

\footnotetext{
${ }^{1}$ Eric ; Jared Cohen Scmidt, Era Baru Digital (Jakarta: Kepustakaa Populer Gramedia, 2013).

${ }^{2}$ Cris Skinner, Digital Human (Cornwall: Wiley, 2018).

${ }^{3}$ Daniel; Teguh Dwi Putranto Susilo, "Indonesian Youth on Social Media: Study on Content Analysis," Advances in Social Science, Education and Humanities Research 113 (2017): 94-97.
} 
news digitally, and so on ${ }^{4}$. In the commerce and industry, the government has issued Presidential Decree Number 74 of 2017 concerning Roadmap of Electronic-Based National Trade System (Road Map E-Commerce). The regulation is intended to give direction to the development of Indonesian e-commerce, which includes aspects of funding, taxation, consumer protection, education, and human resources, logistics security, and cyber security.

As in other fields, the use of information technology also brought major changes in the financial services sector. The use of information technology enables consumers to get better services, have more choices, simpler transaction chains, and cheaper operational costs. While from a macroeconomic perspective, financial technology (fintech) can encourage the transmission of economic policies, increase economic growth, and expand financial inclusion. ${ }^{5}$

The Oxford Dictionary define fintech as "Computer program and other technology used to support or enable banking and financial services". ${ }^{6}$ While according to Fintech Weekly, Fintech is a business that aims at providing financial services by making use of software and modern technology. A more concise understanding is conveyed by National Digital Research Centre, "Innovation in financial services".

Legally, the definition of fintech was formulated in Article 1 paragraph (1) of The Central Bank of The Republic of Indonesia (BI) Regulation (PBI) Number 19/12/PBI/2017 concerning the Implementation of Financial Technology, namely: ${ }^{8}$

"The use of technology in the financial system that produces new products, services, technology and/or business models, and can have an impact on financial system stability, and/or efficiency, smoothness, security and reliability of the payment system".

In general, it can be concluded, fintech is a technological innovation in financial services that can produce business models, applications, processes, or products related to the provision of financial services. Digital revolution implemented in the financial sector is known as Fintech, which is an acronym for the words "Financial and Technology". In that case, fintech derives

\footnotetext{
${ }^{4}$ Chris ; Chris Clarke Rogers, "Mainstreaming Social Finance: The Regulation of The Peer-to-Peer Lending Marketplace in The United Kingdom," The British Journal of Politics and International Relations 18, no. 4 (2016): 930-45.

${ }^{5}$ Puja ; Namita Sahay; O.S. Deo Dua, "Role of Fintech in Financial Inclusionand Financial Integration," Research Review International Journal of Multidisciplinary 4, no. 5 (2019): 1416.

6 "Oxford Learner's Dictionary," April accessed 21, 2020, https://www.oxfordlearnersdictionaries.com/definition/english/fintech?q=fintech.

${ }^{7}$ Svetlana ; Irina Kuzmina-Merlino Saksonova, "Fintech as Financial Innovation - The Possibilities and Problems of Implementation," European Research Studies Journal 20, no. 3A (2017): 961-73.

${ }^{8}$ Article 1 paragraph (1) of The Central Bank of The Republic of Indonesia (BI) Regulation Number 19/12/PBI/2017 concerning The Implementation of Financial Technology.State Gazette of the Republic of Indonesia of 2017 Number 245.
} 
from the coupling of two complementary areas: financial services and solutions based on advanced technology. The economic literature does not agree on a single definition of fintech due to the overall diversity of the business. ${ }^{9}$

Fintech industrial ecosystems develop along with changes in people's lifestyles, especially those related to the use of information technology, which requires fast service. Through fintech, problems that arise due to limited space in the transaction can be overcome. Thus, fintech helps buying and selling transactions, payment systems, or borrowing money to be more efficient and economical. ${ }^{10}$ In terms of service providers, fintech can simplify the transaction process, as well as reduce operational and capital costs. While from a macroeconomic perspective, fintech service has a positive impact. Money circulation is faster so that it can improve the economic welfare of the community, stimulate the transmission of economic policies, and expand national financial inclusion and literacy.

A direct consequence of the development of information technology is the rise of fintech companies, companies that use technology to create a more efficient financial system. In general, many fintech services develop in six types of industries, including: ${ }^{11}$ (a) Payments and transfers, using fintech for payment instruments; (b) Lending and financing, using fintech as a means of lending and borrowing money; (c) including crowfunding and equity participation; (d) Retail banking, using fintech in the banking system; (e) Financial management, using fintech as a tool for managing finance and providing financial data; (f) Insurance, using fintech in the insurance industry, especially as agents and brokers; and (g) Markets and exchanges, using fintech as an investment medium.

Furthermore, according to PBI 19/2017, the organization of Fintech is grouped into several categories, namely: ${ }^{12}$ a). Payment system; b). Market support; c). Investment management and risk management; d). Loans, financing, and capital provision; and e). Other financial services. In the general explanation of Article 3 paragraph (1) letter e, what is meant by other financial service phrases, is in addition to payment system categories, market support, investment management and risk management, as well as loans, financing and capital provision.

\footnotetext{
${ }^{9}$ Bernado Nicoletti, The Future of Fintech: Integrating Finance and Technology in Financial Services (Rome: Palgrave Macmillan, 2017).

${ }^{10}$ Rogers, "Mainstreaming Social Finance: The Regulation of The Peer-to-Peer Lending Marketplace in The United Kingdom."

${ }^{11}$ Kusumaningtuti S. ; Cecep Setiawan Soetiono, Literasi Dan InklusiKeuangan Indonesia (Jakarta: Rajawali Press, 2018).

${ }^{12}$ Article 1 paragraph (1), Ibid.
} 
Based on the fintech service category described above, this article will discuss fintech implementation in Indonesia, to describe the business ecosystem and legal framework that currently applies. Then the discussion will be directed to elaborating legal issues arising from digital payment industry and peer to peer (P2P) lending or digital lending business practices. The main legal issue to be examined is how is law enforcement in the fintech business, especially digital payment and peer to peer lending?This study is important to support the creation of new laws that can accommodate changes and needs that are taking place in society.

\section{Methods}

This research was designed using the normative juridical research method through the prevailing statutory approach. This approach is carried out to study fintech in the legal system in Indonesia. Research has been conducted by way library research which started from the prevailing regulations on the landscape of fintech industry. The primary legal consists ofFinancial Services Authority (OJK) and Indonesia Central Bank Regulations, covering: POJKNo. 01/POJK. 07/2013 abouttheProtectionofConsumersof Financial Services Sectors;POJKNo. 77/POJK.01/2016 concerning Information Technology-BasedLending Services; POJK No. 13/POJK.02/2018 concerning Digital Financial Innovations in the Financial Services Sector,dan POJK Number 37/POJK.04/2018 concerning Funding Services through Equity Crowdfunding, Circular Letter No. 12/SEOJK.07/2014 concerning Provision of Information for Marketingof Financial Productsand/or Services, and PBI Number 19/12/PBI/2017 concerning the Implementation of Financial Technology.

\section{Results and Discussion}

\subsection{Fintech Category and Its Business Ecosystem}

The first platform is peer to peer ( $\mathrm{P} 2 \mathrm{P})$ lending and crowdfunding. This one platform brings together those who need funds with those who are willing to provide funds. P2P lending facilitates and brings together the interests of those who want to need a loan with other parties who want to invest. Through this platform, the process of borrowing, investing and providing funds tends to be more practical compared to conventional banks. This condition occurs because the service is carried out in one platform. Actually, fintech in Indonesia is encouraged to be able to provide the financing needed by micro, small and medium enterprises, and to support the achievement of the Indonesian government's goals in terms of financial inclusion. 
Compare with P2P lending, crowdfunding is more social. This system allows the collection of funds from the wider community to finance certain projects. Crowfunding is the process of one party requesting and receiving money and other resources from many individuals for financing a project, in exchange for monetary or non-monetary return on investment. ${ }^{13}$

The second platform are risk management and investment. Through this category of fintech, you can manage your personal finances, manage risk since planning in practice. Another platform is the market aggregator. In this category, the platform collects financial related information to be conveyed to its users. This information varies, can be about general tips for organizing, investing, to credit card information. By using a market aggregator, we are expected to be able to make better decisions, because we have good information. ${ }^{14}$

Moreover, the next platforms are payment, clearing, and settlement. Research has found that the platform most frequently used in this category is the payment platform. ${ }^{15}$ Based on OJK records in 2019, digital payments reached 39\% of Fintech's business in Indonesia. At the moment, we can make cardless and cashless payments via smartphones. Some fintech services have features to transfer to banks, pay various monthly bills, such as electricity, telephone, internet and insurance bills. Through these services, we can save time and energy because we do not need to leave the house to make these transactions.

Money plays an important role in the economy of a society. Starting from simple transactions with exchange of goods (barter), then the mechanism of trade and payment developed through various payment instruments whose exchange rates were mutually agreed upon, ranging from copper, coins and banknotes first used in 1661. Currently, the use of cards (e-cards) are commonly used and information technology encourages digital payments through electronic transactions.

Mid-August 1994 was remembered as an important event, which opened the door for the era of internet commerce. When the first time a safe commercial online payment was received by NetMarket, a retail company from the United States. In the not too distant future, followed by Amazon and e-Bay (1995), Google (1998), PayPal (1999), and Alibaba (1999). ${ }^{16}$ For 20 years,

${ }^{13}$ K.J.M. Voorbraak, Crowd Fundingf or Financing New Ventures: Consequences of the Financial Model on Operational Decisions (Eindhoven: Eindhoven University of Technology, 2011).

${ }^{14}$ Thomas Kohlborn..et.al, "Service Aggregators in Business Networks," 2009.

15 Mohammad Auwal; Siti Zabedah Saidin; Aidi Ahmi Kabir, "Adoptionof E-Payment Systems: A ReviewofLiterature," in Proceedings of the International Conference on E-Commerce, 2015, 112-20.

${ }^{16}$ Alibaba and Tencent made a break throughwit the QR-based payment system, the two Chinese companies succeeded in transforming the 1.3 billion peopleintotheworld'sfirstcashlesssociety. Tencenttook a strategic step bybuying 40 percent of Go-Jek's shares worth 1.2 billion dollars, which made it the main share holder of Go-Jek, in 
online retail trade reached a value of no less than 100 billion pounds in the United Kingdom. Now, PayPal is a company from the United States that is known as a market leader in the digital payment industry in Europe and the United States. This position was enjoyed by Yandex.Money for the Russian market, and AliPay for the Chinese market. ${ }^{17}$

As a global phenomenon, Fintech has developed rapidly in several countries. In the UK, digital-based financial services have doubled every year. So that in the past four years lending exceeded $£ 1$ billion in 2014, and $£ 2$ billion in 2015 . $^{18}$ The record shows, the UK is a leader in alternative financial markets in the European Union. For 2014, alternative financial markets throughout the European Union posted a figure of $€ 2.9$ billion, but only $€ 620$ million outside the UK. Overall alternative finance, grew 144 percent in 2014 in the European Union other than in the UK, compared to 2013. The UK is home to a number of alternative financial platforms, followed by Spain, France, the Netherlands and Germany. ${ }^{19}$

The trend of cashless transaction payments is increasingly popular. In the future, the form and amount of electronic payments is expected to continue to increase. Since 2014, Bank Indonesia (BI), as the monetary authority, has been actively promoting "Gerakan Nasional Nontunai". This policy is expected to reduce costs, which include the cost of producing rupiah currency, operational costs, and transportation costs and the distribution of remittances to various parts of Indonesia. In 2019, the non-cash payment electronification program will be expanded to meet the fourth generation industrial era, the internet of things (IoT) era. ${ }^{20}$

Non-cash transactions originate from the use of cards and automated teller machines (ATMs), which have become known since the 1990s. Information technology allows non-cash financial transactions to be carried out using an electronic card. Currently the transaction service has been developed by digital payment application providers such as GoPay (PT Gojek Indonesia), OVO (PT Visionet International), DANA (PT. Elang Sejahtera Mandiri/ESM), BukaDompet (BukaLapak), TokoCash (Tokopedia), ShopeePay (Shopee), DOKU (PT. Elang Mahkota Teknologi), and LinkAja (PT. Fintek Karya Nusantara/Finarya). The banking sector is

mid-2017. Tencent wanted to make Go Pay as We Chat from Indonesia, and as an entry point to master the business payment system in Indonesia.

${ }_{17}^{17}$ Skinner, Digital Human.

${ }^{18}$ Skinner.

${ }^{19}$ Channel, "Pesatnya Perkembangan Fintech Dorong Kemajuan Ekonomi Digital,” 65th ed., 2016.

${ }^{20}$ The internet era for all (IoT) is marked by the connection of all devices with internet networks. By utilizing robotics and artificialintelligence, a chipcanbeplaced in anydevicethatwillmakeitsmart. Sothatsmartroadsemerge, smartbuildings, smarttoilets, smartparkinglots, smartcities, andsoon. 
competing to deliver m-banking applications, which make it easier for users to make non-cash transactions anywhere and anytime, as long as there is an internet connection.

The development of non-cash transactions is also supported by increasing the digital lifestyle in the community, especially the millennial generation who prefer to use payment services such as e-wallet. BI data shows that electronic money transactions in 2018 reached Rp. 47.2 trillion, up 291 percent compared to 2017 at 12 trillion. In 2019, transactions are projected to increase along with increasing card issuance, transactions, and the number of new users. Massive payment electronification can reduce the money supply. However, for the outermost regions, the authorities need to ensure adequate circulation of money. Not only because these areas still experience limitations in telecommunications infrastructure, but the physical appearance of national currency money in the border area is a manifestation of the sovereignty of the Indonesian state.

The development of non-cash transactions is also supported by increasing the digital lifestyle in the community, especially the millennial generation who prefer to use payment services such as e-wallet. ${ }^{21} \mathrm{BI}$ data shows that electronic money transactions in 2018 reached Rp. 47.2 trillion, up 291 percent compared to 2017 at 12 trillion. In 2019, transactions are projected to increase along with increasing card issuance, transactions, and the number of new users. Massive payment electronification can reduce the money supply. However, for the outermost regions, the authorities need to ensure adequate circulation of money. Not only because these areas still experience limitations in telecommunications infrastructure, but the physical appearance of national currency money in the border area is a manifestation of the sovereignty of the Indonesian state.

The Morgan Stanley Annual Report, an investment bank from the United States, is interesting to observe. During the year 2018, the digital payment market in Indonesia rose by 7.3 percent, with a transaction value of 47.1 trillion. Until the end of 2019 , transaction growth is projected to be at least 10 percent $^{22}$. This development was supported by the trend of using digital wallets, which are increasingly popular in the community. The GoPay application, as a pioneer of e-wallet in the country, is still listed as the market leader, with transactions reaching 50 million times per month. While the GoJek application has been downloaded more than 108 million times. Noted, as many as 50 percent of transactions on this platform use GoPay. Since

\footnotetext{
${ }^{21}$ Anirban ; Pery Price; Vincent Bastid Bose, World Fintech Report 2018 (Capgemini \&Efma, 2018).

${ }^{22}$ Morgan Stanley, "Disruption Decoded: Who Will Win in ASEAN e-Payments?," morganstanley.com, 2018, https://www.morganstanley.com/ideas/asean-epayments.
} 
the fast response code (QR Code) was launched in April 2018, GoPay transactions jumped 25fold. GoPay is followed by other market players, OVO, and LinkAja.

This time, the use of electronic money is still the highest in the transport sector. Most mass transportation in Jakarta began to abandon conventional transactions, shifting to digital payments, such as the transportation mode of the Electric Rail (KRL), Moda Raya Terpadu (MRT), and payments on the toll road. During the Idul Fitri 2019 holiday period, Bank Mandiri noted that the highest transaction occurred in transactions on the freeway. Increased transactions through e-money Mandiri, increased by 30 percent, compared to the previous year period. In addition to the transportation sector, high electronic transactions also occur in the entertainment sector. Based on the records of PT. Bank Negara Indonesia, Tbk (BNI), BNI's digital payment instrument, TapCash, has supported many events held by corporations, as well as other parties, through expansion of card acceptances.

In the transportation sector, it is not only banks that issue electronic money. Two transportation companies, such as PT. Indonesian Commuter Train (KCI) and PT. Transportation Jakarta (Transjakarta), also participates in issuing similar cards. KCI's Multi-Trip Card (KMT), since 2013, is in line with the entry into force of the electronic ticketing system on the Commuter Line KRL service. While Transjakarta has distributed JakLingko Cards, since the end of 2018, which can be used for Transjakarta transportation modes and other road-based integrated transportation. However, KMT and JakLingko cannot be used to pay for transactions outside of transportation, such as transactions with retail companies.

The trend of digitalization of the financial sector can change the risk landscape significantly, namely increasing cyber threats, monopolistic competition, and shadow banking which can reduce the effectiveness of monetary control, financial system stability and smooth payment systems. For this reason, BI has prepared five visions of the Indonesian payment system (SPI) in 2025, which essentially supports digital economic integration and banking digitalization, and guarantees interlink between Fintech and banks. In addition, SPI's vision guarantees the balance of innovation with consumer protection.

Every company that organizes Fintech service payment systems (payment, clearing and settlement), and other digital-based financial services, must be under the supervision of BI and OJK. In this category, business models are developed for example, the use of funds transfers, emoney, electronic wallets (e-wallets), and mobile payments. BI data shows, until March 201934 companies have registered in the form of limited liability companies (PT), which obtain 
operational permits. ${ }^{23}$ Examples of these service products include: Brizzi (PT. Bank Rakyat Indonesia), Pay Pro (PT. Indosat, Tbk), Vas Card (PT. Telekomunikasi, Tbk), Flazz (PT. Bank Central Asia, Tbk), and e -money Mandiri (PT. Bank Mandiri, Tbk).

In addition, Fintech services in Indonesia also include market support services, which provide comparative data on information on financial products or services. Other activities include financing or funding services through offering information technology-based shares (equity crowdfunding). The two service providers are, KitaBisa.com (KitaBisa Foundation) and Wujudkan.com (PT XL Axiata, Tbk).

\subsection{Strengthening Regulations in the Peer to Peer Lending Business}

The activity of borrowing money is directly based both written and unwritten agreements are practices has taken place in the middle of people's lives. This activity is in demand by parties who need funds quickly or parties who for some reason cannot be provided funding by conventional financial services industries such as banking, capital markets, or financial companies. In civil law, the legal consequences of borrowing and borrowing activities carried out directly are entirely the responsibility of the parties in accordance with the agreed agreement. Information technology based lending and borrowing services increase public access toonline financial services products with various parties without need to know each other. ${ }^{24}$

The use of the P2P model in finance was first carried out by a British company named Zopa in 2005. Since then, this field of peer-to-peer lending has grown rapidly in the world, especially in the United Kingdom and America ${ }^{25}$. The P2P lending industry is also growing rapidly to Europe, Australia and Asia such as China. This lending company arises as a result of two main things, namely because the reach of conventional loan providers is limited due to stringent requirements so that the impact on limited access to loans, as well as existing banking products cannot meet the needs of today's society which continues to increase.

In brief, peer to peer lending platforms are defined as peer-to-peer (P2P) lending platforms are online marketplaces bringing together borrowers and lenders/investors, andofferingquick, lowcost, technology driven solutions. P2P lending permits individuals to borrow as well as lend

\footnotetext{
23 “No Title," accessed April 20, 2020, https://www.bi.go.id/id/sistem-pembayaran/informasi-perizinan/uangelektronik/penyelenggara-berizin/Pages/default.aspx.

${ }^{24}$ Naoko ; David Storey ; Bihong Huang Nemoto, "Optimal Regulationof P2PLending ForSmalland Medium-Sized Enterprises,” ADBI Working Paper Series, No. 912, 2019.

${ }^{25}$ Amy; Kathleen Yawosky; Paul Lamont Stewart, Demystifyng Digital Lending (ACCION Insight, 2018).
} 
without the need of financial institutions or banks as intermediaries. ${ }^{26}$ Legally, P2P platforms are online market places bringing together borrowers and lenders/investors, and offering quick, lowcost, technology driven solutions. Digital lending permits individuals to borrow as well as lend without the need of financial institutions or banks as intermediaries. ${ }^{27}$

The P2P lending industry is expected to increasingly experience rapid development both in the world and in Indonesia. This happens for two reasons: the use of increasingly sophisticated technology and a number of competitive advantages possessed by the P2P lending platform when compared to conventional financial institutions such as banks. These advantages include P2P lending offering better returns compared to deposits at banks and low interest rates for borrowers, the possibility of channeling funds for borrowers who cannot access loan funds from banks, the perception that $\mathrm{P} 2 \mathrm{P}$ lending is more responsible and has social value higher than conventional banks, and technological innovations that can improve the quality and speed of service for borrowers and financiers. ${ }^{28}$

To conduct a P2P lending business, OJK also requires a minimum capital ownership of Rp 1 billion at the time of registration. And after applying for a permit, the capital must be increased to reach Rp 2.5 billion. In addition, in order to protect the interests of national financial system stability, the number of loans is limited to a maximum of Rp 2 billion in rupiah. ${ }^{29}$ Regulations and supervision are very important for the sustainability of fintech in Indonesia. This relates to the legality of the business being carried out because in its implementation the development of fintech has potential risks which are related to consumer protection, financial system stability, payment systems and economic stability. The purpose of regulation and supervision by OJK is to minimize these risks and support sustainable and stable economic growth

Indonesia's Fintech Report data shows that inter-party loan category services are growing rapidly compared to other categories. Throughout 2018, this service covers $31 \%$ of all fintech businesses, under the digital payment service that controls the industry by $38 \%$. Based on data from the OJK, as of January 2019, this digital loan distribution was recorded at Rp 25.92 trillion. This number grew $14.36 \%$ compared to the previous year, amounting to Rp 22.67 trillion. ${ }^{30}$

\footnotetext{
${ }^{26}$ Derayah Financial, “A Concept Study OnPeer-to-PeerLending,” 2019.

${ }^{27}$ Article 1 (3) POJK 77/2016.

${ }^{28}$ Alistair; Paul Parboteeah Milnea, “The Business ModelsandEconomicsofPeer-to-PeerLending," ECRI Research Report 19 (2016): 1-35.

${ }^{29}$ Article 4 POJK 77/2016.

${ }^{30}$ Daily Social dan Otoritas Jasa Keuangan, “Fintech Report 2018,” 2018.
} 
In the last two years, the dynamics of digital loans have received much public attention. Not only due to rapid business growth, but also because of legal problems that arise, along with the number of service users (consumers). ${ }^{31}$ The increasing needs of the community for the availability of fresh funds have stimulated this business to continue to grow. The ease in the financing process and the lack of requirements become the business attraction. Without a faceto-face meeting and a complicated process, the loan proposal can be approved by the disbursement.

The emergence of companies that serve loans on the one hand can expand financial inclusion and increase public access to formal financing services. On the other hand, there have also been a variety of legal violations that harm the public (consumers), especially those caused by illegal fintech companies. Ironically, the increase in illegal companies is more than the legal companies. The legality of the company refers to the licenses granted by the Financial Services Authority (OJK). Consequently, every fintech company must obtain a permit business, approval, registration, endorsement, or effective statement from OJK.

In accordance with regulations, fintech companies are required to obtain operating licenses from OJK, by registering legal entity establishment certificates, ownership records, shareholder data, as well as directors and commissioners, as well as other company documents. The closure of a number of illegal fintech companies are always followed by the appearance of similar entities. In general, online loans are offered at around 1-2\% per day, or 30-60\% per month. In spite of, the loan interest from the official fintech application only ranges from $0.8 \%$ per day, or 24 percent per month. ${ }^{32}$ While banking interest is around $12 \%$ per year, or $1 \%$ per month. Therefore, understandably, digital lending leads to moneylender practices, a dishonorable business practice with a new style.

As a result, not only interest is very pressing for customers, but also the method of billing illegal fintech companies is very troubling. There are those who argue that, the mode of billing was through short message terror, continuous telephone calls, sexual harassment, excessive interest on loans, and intimidation at the borrower's workplace. In the most tragic cases, even service users who are late paying their debts can experience severe depression. Unlike the official fintech application, illegal P2P lending activities show unusual features, such as not including company names and office addresses. The e-mail address used is mostly using a free

\footnotetext{
${ }^{31}$ Lauren Saunders, "Fintech and Consumer Protection: A Snapshot," National Consumer Law Center March (2019): 1-22.

${ }^{32}$ Kompas, "No Title," Kompas, 2019.
} 
domain. In fact, some e-mails are a combination of letters and numbers, which are not commonly used for e-mailing commercial companies.

\subsection{Consumer Protection and Law Enforcement}

More than in other sectors, finance is the highest regulated sector including matters relating to consumer protection. Basically, consumer protection includes a variety of topics, but not limited to productliability, privacy rights, unfair business practices, fraud, misrepresentation, other business/consumer interaction ${ }^{33}$. In order to provide consumer protection, Financial Services Autority (OJK) has issued regulation, namely POJK No. 01/POJK. 07/2013 about the Protection of Consumers of Financial Services Sectors. Based on this regulation, financial service institutions are required to provide and/or convey information about products and/or services that is accurate, honest, clear, and not misleading.

In line with the development of digitalization of the financial sector, security risks will always be appear. Various loopholes and a new mode of crime have evolved as technology advances. In non-cash transactions through cards, for example, the most common mode is skimming. Criminals steal debit or credit card information through a magnetic stripe of cards, to access and control victims' accounts. Another type of crime is pishing, which is fraud by tricking victims into stealing user IDs and passwords/PINs, and credit card numbers.

Online payment systems are not free from the risk of crime which is increasingly complicated handling. One mode of crime is through the spread of malware, a type of software that can enter the user's victim's computer and manipulate the appearance of e-banking websites, as if it belongs to the bank where the user becomes a customer. Through this mode, the perpetrator deflects the customer's cash flow into the holding account after controlling the victim's account. In addition, security risks can also occur in digital wallet services.

Since 2013, BI has established the Payment System Consumer Protection Division, to respond to increased payment transactions and strengthen commitment to the interests of consumers. The main functions of this division are education, consultation and facilitation. Through the education and consultation function, BI provides information and socialization to consumers who want to get knowledge about payment system service products. Whereas the facilitation function is the handling of disputes between consumers and providers of payment system services indicated by financial losses. The scope of BI's consumer protection includes six

\footnotetext{
33 Sari Murti; Johanes Widijantoro Widiyastuti, “The Roleof Financial Services Authorityin The Consumer Protection Amid the Growthof Fintech Industry in Indonesia," MIMBAR HUKUM 31, no. 2 (1019): 297-308.
} 
activities, namely: Issuance of funds transfer instruments and/or withdrawals of funds; transfer of funds; card payment (ATM/debit and credit card); electronic money activities; supply and/or deposit of rupiah money; and the implementation of other payment systems determined by BI.

Based on applicable regulations, not all consumer complaints are handled by the authorities. BI stipulates several conditions that must be met, namely: consumers have submitted complaints to the organizers; there is no agreement between the consumer and the organizer; complaints are civil matters that are not in the process or have not been decided by mediation, arbitration or judicial institutions; and cause financial losses to consumers. In addition, BI established a forum for communication with banks to monitor crime practices in digital financial institutions, as well as establish cooperation with units of cybercrime, Indonesian police.

On the other hand, the organizers must encourage financial literacy to consumers. Communities need clear information regarding the characteristics of payment products and services, both benefits and potential risks. Correct information and good financial literacy are the main aspects of consumer protection. Community awareness and independence need to be encouraged to increase transaction security efforts. At present, the monetary authority has issued and is formulating several regulations to guard the dynamic of digital financial innovation. Some of the regulations include electronic money, the implementation of financial technology, the National Payment Gate (GPN), and the implementation of digital finance.

The Bank Indonesia Regulation (PBI) has been renewed at least three times, the last being PBI Number 20/6/PBI/2018 concerning Electronic Money. In the latest provisions, the regulator requires foreign electronic money providers, such as WeChat Pay and AliPay (from China), to deposit capital and share with national banks if they want to operate in Indonesia. ${ }^{34}$ The collaboration is under the supervision of the authority, including processing transaction data and consumer data protection. Currently the payment transaction standard is being compiled using the Quick Response Code (QR Code) feature, which is the Quick Response Code Indonesia Standard (QRIS).

As part of consumer protection, the QRIS trial involves 19 banks and electronic moneyreceiving companies, and will begin to be implemented after the second half of 2019. The QR feature allows interconnected payments with several digital payment applications using one standard, so as to encourage penetration, this provision will be regulated through PBI regarding

\footnotetext{
${ }^{34}$ The composition of share ownership of at least 51 percent (fiftyonepercent) of its sharesis owned by Indonesian citizens; andor Indonesian legal entities (Article 10 paragraph (1) PBI 20/6 PBI /2018 concerning Electronic Money).
} 
transaction processing. The standard is an effort to help accelerate the development of digital economy and finance.

Business collaboration between banking and Fintech industries needs to be regulated through appropriate regulations, to maintain trust in the national financial system. PBI 19/2017 concerning the Implementation of Financial Technology and Regulations of BI Board of Governors (PADG), periodically needs to be assessed for their relevance. Mainly related to registration procedures, report achievement, minimum capital ownership limits, business model monitoring (business model), and limited testing (regulatory sanbox). ${ }^{35}$ The study is needed to ensure that financial innovations are safe, well-managed risks, and promote consumer protection.

Based on article 5 POJK No. 01/POJK. 07/2013 about the Protection of Consumers of Financial Services Sectors, financial service institutions are required to submit information uptodate and easily accessible to consumers about products and/or service. It follows that, complete and correct information containing the identity and status of legal subjects and their competencies, both as producers, suppliers, organizers, as well as intermediaries, as well as other information that explains certain things that become legal conditions of the agreement and explains the products or services offered such as names, and address.

In addition, financial services companies must deliver information regarding products and/or services that are fair based on actual information about the benefits, costs, and risks of each product and/orservice ${ }^{36}$. Clarity of information that is easy to read and understand includes the use of letters, writing, symbols, diagrams, signs, terms, phrases, sentences or symbols, diagrams that can be provide convenience, clarity, and understanding for user. On the contrary, there are many P2P lending businesses, especially illegal companies, do not include their addresses as information provided, or descriptions of products or services offered are incomplete. The situation has the potential to harm consumers.

In practice, the modus operandi of cybercrime is very diverse, so consumers are required to be vigilant in protecting their interests. Awareness of information technology security (IT security awareness). Increasing consumer awareness, ability and independence are the main objectives of consumer empowerment, to be able to protect themselves and their rights as dignified consumers. For the category of Fintech loans between parties, the still weak regulation

\footnotetext{
${ }^{35}$ The Sandbox Regulatory is a mechanismof testing carriedoutbythe Financial Services Authority to assess there liability of business processes, business models, and organizer governance (Article 1 point (4) POJK 13/POJK.02/2018 concerning Digital Financial Innovations in the Financial Services Sector.

${ }^{36}$ Circular Letter No. 12/SEOJK.07/2014 Concerning Provision of Information for Marketing of Financial Products and/or Services, n.d.
} 
and supervision is a gap for businesses to continue to operate to trap consumers, either in the form of abuse of personal data, the application of high loan interest rates, or intimidation in collection $^{37}$.

Strengthening regulations, especially those that regulate the maximum loan interest rates, need to be done immediately. These provisions are not found in POJK 77/2016, as the only policy in the field of online loans. In general, Fintech loans between illegal parties offer loan interest of up to 2 percent per day or 60 percent per month. While companies that officially offer loan interest at a maximum of $0.8 \%$ per day. In addition, POJK 77/2016 does not regulate the dispute resolution mechanism, and submit it to the parties.

With the outbreak of illegal companies that practice P2P lending in society must be addressed with firmer law enforcement. Applying the general criminal code (KUHP) to the perpetrators of the crime proved not to deter. Many illegal companies have been closed by OJK, but there have been more similar companies. This condition is like a process that never ends. It is time to take action and punish illegal fintech companies as the subject of corporate crime with strict sanctions. In the development of criminal law in Indonesia, there are special criminal laws, which have expanded the subject of criminal $\operatorname{law}^{38}$. The application of sanctions against companies as perpetrators of corporate crime is also carried out in several countries ${ }^{39}$.

According to Marshall Clinard and Richard Quinney, "corporate crime refers to situations where corporate officials commit criminal or harmful acts for the benefit of the corporation, while occupational crime refers to situations where individual employees commit crimes against the corporation, workplace, or consumer during the course of employment". ${ }^{40}$ Draft of Criminal Code version 2019 (RUU KUHP 2019) has implemented the corporation as the subject of

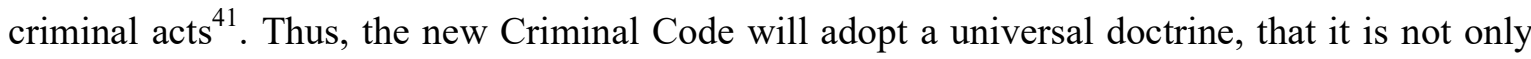
humans who are the subject of criminal acts, but also corporations. Therefore, the requirements to be able to impose criminal liability to corporations in the RUU KUHP 2019 needs improvement.

\footnotetext{
${ }^{37}$ Flore Anne Messy, "FinTech Developments \&Their Consequences for the Financial Industry \&Regulators in Asia \& Beyond," Japan Spotlight, no. September-Oktober (2019): 44-49.

${ }^{38}$ Sutan Remy Sjahdeni, Ajaran Pemidanaan: Tindak Pidana Korporasi Dan Seluk Beluknya (Jakarta: Prenada Media Group, 2017).

${ }^{39}$ Michael J. ; Danielle Mcgurrinb ; Melissa Fenwick Lyncha, "Disappearing Act: The Representation Of Corporate Crime Research in Criminological Literature," Journal of Criminal Justice 32 (2014): 389-98.

${ }^{40}$ Marshall ; Richard Quinney Clinard, "Criminal Behavior Systems," in Ajaran Pemidanaan: Tindak Pidana Korporasi Dan Seluk Beluknya, 2017, 61.

${ }^{41}$ In total, the Criminal Code Bill (RUU KUHP 2019)was completed consisting of 2 books and 629 articles with the following details. The first book is about general rules consisting of 6 chapters and 187 articles. Then the second book about criminal acts consisting of 36 chapters and 442 articles.
} 
In connection with the requirements that must be met so that a criminal offense committed by a person can be liable to the corporation, Article 49 of the 2019 RUU KUHP stipulates as follows:

"A criminal offense is committed by a corporation if it is carried out by persons who have a functional position in the organizational structure of a corporation acting for and on behalf of corporate interests, based on work relationships or based on other relationships, within the scope of the corporation's business, either individually or jointly".

All things considered, If RUU KUHP 2019 has been passed, then illegal fintech companies that conduct business was subject to criminal offenses, which can be sanctioned according to law. As affirmed in article 2 POJKPOJK 77/2016, legal entities that practice fintech business are limited liability companies or cooperatives. In the meantime, to stem the massive development of illegal digital lending, can work together with fintech industry associations to educate and socialize the public. This activity is important to do to mitigate risks and legal problems that arise in the community. OJK needs to implement strict administrative sanctions against illegal fintech companies, in accordance with Article 4 POJK 77/2016. In this regulation, OJK has the authority to impose administrative sanctions on the companies, in ways: written warning, restrictions on business activities, and revocation of permission.

\section{Conclusions}

The fintech business landscape in Indonesia is dominated by fund-raising services and P2P lending. Both of these fintech categories grow and develop dynamically, along with the widespread use of the internet in the community. The rise of fintech companies that practice P2P lending illegally on the one hand raises legal issues that are detrimental to the community, on the other hand it can damage the image and a healthy business climate. Building a healthy business ecosystem cannot be separated from law enforcement. Thus, the legal instruments governing the fintech business need to be improved. The 2019 Criminal Code Bill that regulates corporate crime needs to be ratified immediately, so that it can be used as an instrument of law enforcement.

The growth of internet users in Indonesia makes Indonesia a digital economy market with a dynamic ecosystem of e-commerce and Fintech businesses. This condition needs to be supported by regulations that are accommodative of changes and protection of the interests of customers who have a higher position than business protection. The emergence of various modus operandi for cyber crime and the operation of the illegal fintech company show two things. First, weak 
regulation and supervision from the authorities, and secondly, there is still limited public literacy towards the fintech business. These two things not only can hamper the creation of a conducive business ecosystem, but also can erode public confidence in the national financial system. To prevent the establishment of illegal financial entities, adequate regulations are needed to improve the coordination of regulators, law enforcement, and employers' associations, so that supervision is more effective. Further research is needed to identify legal issues that arise in the Fintech business in each of the financial service categories, thus identifying them more specifically.

\section{Acknowledgement}

On this occasion, we would like to express our sincere thanks to the leaders of Universitas Bhayangkara Jakarta Raya, who have provided the necessary financial support and facilities for this research.

\section{References}

Bose, Anirban; Pery Price; Vincent Bastid. World Fintech Report 2018. Capgemini \&Efma, 2018.

Channel. "Pesatnya Perkembangan Fintech Dorong Kemajuan Ekonomi Digital.” 65th ed., 2016.

Circular Letter No. 12/SEOJK.07/2014 Concerning Provision of Information for Marketing of Financial Products and/or Services, n.d.

Clinard, Marshall ; Richard Quinney. "Criminal Behavior Systems.” In Ajaran Pemidanaan: Tindak Pidana Korporasi Dan Seluk Beluknya, 61, 2017.

Daily Social dan Otoritas Jasa Keuangan. "Fintech Report 2018,” 2018.

Dua, Puja; Namita Sahay; O.S. Deo. "Role of Fintech in Financial Inclusionand Financial Integration.” Research Review International Journal of Multidisciplinary 4, no. 5 (2019): 1416.

Financial, Derayah. “A Concept Study OnPeer-to-PeerLending,” 2019.

Kabir, Mohammad Auwal ; Siti Zabedah Saidin ; Aidi Ahmi. “Adoptionof E-Payment Systems: A ReviewofLiterature." In Proceedings of the International Conference on E-Commerce, $112-20,2015$.

Kohlborn..et.al, Thomas. "Service Aggregators in Business Networks," 2009.

Kompas. "No Title.” Kompas. 2019.

Lyncha, Michael J.; Danielle Mcgurrinb; Melissa Fenwick. "Disappearing Act: The 
Representation Of Corporate Crime Research in Criminological Literature.” Journal of Criminal Justice 32 (2014): 389-98.

Messy, Flore Anne. "FinTech Developments \&Their Consequences for the Financial Industry \&Regulators in Asia \& Beyond.” Japan Spotlight, no. September-Oktober (2019): 44-49.

Milnea, Alistair ; Paul Parboteeah. "The Business ModelsandEconomicsofPeer-to-PeerLending." ECRI Research Report 19 (2016): 1-35.

Nemoto, Naoko; David Storey; Bihong Huang. "Optimal Regulationof P2PLending ForSmalland Medium-Sized Enterprises.” ADBI Working Paper Series, No. 912, 2019.

Nicoletti, Bernado. The Future of Fintech: Integrating Finance and Technology in Financial Services. Rome: Palgrave Macmillan, 2017.

"No Title." Accessed April 20, 2020. https://www.bi.go.id/id/sistem-pembayaran/informasiperizinan/uang-elektronik/penyelenggara-berizin/Pages/default.aspx.

“Oxford Learner's Dictionary.” Accessed April 21, 2020. https://www.oxfordlearnersdictionaries.com/definition/english/fintech?q=fintech.

Rogers, Chris ; Chris Clarke. "Mainstreaming Social Finance: The Regulation of The Peer-toPeer Lending Marketplace in The United Kingdom." The British Journal of Politics and International Relations 18, no. 4 (2016): 930-45.

Saksonova, Svetlana; Irina Kuzmina-Merlino. "Fintech as Financial Innovation - The Possibilities and Problems of Implementation.” European Research Studies Journal 20, no. 3A (2017): 961-73.

Saunders, Lauren. "FintechandConsumerProtection: A Snapshot." National Consumer Law Center March (2019): 1-22.

Scmidt, Eric ; Jared Cohen. Era Baru Digital. Jakarta: Kepustakaa Populer Gramedia, 2013.

Sjahdeni, Sutan Remy. Ajaran Pemidanaan: Tindak Pidana Korporasi Dan Seluk Beluknya. Jakarta: Prenada Media Group, 2017.

Skinner, Cris. Digital Human. Cornwall: Wiley, 2018.

Soetiono, Kusumaningtuti S.; Cecep Setiawan. Literasi Dan InklusiKeuangan Indonesia. Jakarta: Rajawali Press, 2018.

Stanley, Morgan. "Disruption Decoded: Who Will Win in ASEAN e-Payments?" morganstanley.com, 2018. https://www.morganstanley.com/ideas/asean-epayments.

Stewart, Amy; Kathleen Yawosky; Paul Lamont. Demystifyng Digital Lending. ACCION Insight, 2018. 
Susilo, Daniel ; Teguh Dwi Putranto. "Indonesian Youth on Social Media: Study on Content Analysis." Advances in Social Science, Education and Humanities Research 113 (2017): 94-97.

Voorbraak, K.J.M. Crowd Fundingf or Financing New Ventures: Consequences of the Financial Model on Operational Decisions. Eindhoven: Eindhoven University of Technology, 2011. Widiyastuti, Sari Murti ; Johanes Widijantoro. "The Roleof Financial Services Authorityin The Consumer Protection Amid the Growthof Fintech Industry in Indonesia." MIMBAR HUKUM 31, no. 2 (1019): 297-308. 